\title{
Past, present and future of the Spanish labour market: when the pandemic meets the megatrends
}

\author{
Juan J. Dolado \\ Universidad Carlos III de Madrid and CEPR, \\ Getafe, Spain \\ Florentino Felgueroso
}

Fundación de Estudios de Economía Aplicada (FEDEA), Madrid, Spain, and

Juan F. Jimeno

Banco de España, Universidad de Alcalá, CEPR and IZA, Madrid, Spain

\begin{abstract}
Purpose - This paper aims to review the experience so far of the Spanish labour market during the Covid-19 crisis in the light of the existing institutions, its performance during past recessions and the policy measures adopted during the pandemic. Emphasis is placed on the role of worldwide trends in labour markets because of automation and artificial intelligence, in shaping a potential recovery of this (hopefully) transitory shock through a big reallocation process of employment and economic activity. It also highlights some innovations to employment and social policies needed to smooth the reallocation process and lessen the rise in inequality associated to technological trends.
\end{abstract}

Design/methodology/approach - Theory and empirics.

Findings - The Spanish labour market will subject to a great reallocation shock as a result of Covid-19 and secular technological changes. Reforms need to be undertaken.

Originality/value - An overview and some new results.

Keywords Labour market, Automation, Epidemic, Flows, Labour market flows

Paper type Research paper

\section{Introduction}

As in past recessions, the Spanish labour market has been one the worst hit by Covid-19 worldwide. The response to the pandemic has led to sharp falls in labour demand in many sectors. Non-essential retail, hospitality and leisure businesses have been closed down at

(C) Juan J. Dolado, Florentino Felgueroso and Juan F. Jimeno. Published in Applied Economic Analysis. Published by Emerald Publishing Limited. This article is published under the Creative Commons Attribution (CC BY 4.0) licence. Anyone may reproduce, distribute, translate and create derivative works of this article (for both commercial and non-commercial purposes), subject to full attribution to the original publication and authors. The full terms of this licence maybe seen at http:// creativecommons.org/licences/by/4.0/legalcode

The authors are grateful to an Associate Editor for useful comments. Dolado and Felgueroso thank financial support from the Ministerio de Economía y Competitividad (grant ECO2017-83255C3-P), Fundación BBVA (Ayudas a Equipos de Investigación Científica Sars-Cov-2 y Covid-19) and Fedea, respectively. The views expressed in this paper by Jimeno should not be interpreted as reflecting the views of the Banco de España.

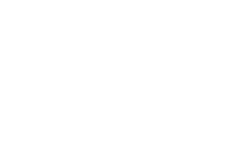


AEA 29,85

different stages and industries such as air travel have largely halted due to restrictions. These sectors alone employed over 6.3 million workers in Spain (more than $30 \%$ of total employment) on the eve of the crisis. By adding in the knock-on effects of these closures on other industries in those sectors' supply chains, the proportion of the Spanish workforce left jobless is at risk of rising to unprecedented heights. Policy responses have focused heavily on preventing severance of employment ties in struggling sectors (essentially, encouraging "labour hoarding" by subsidizing short time work and furloughs) while protecting the incomes of those workers by subsidizing their wages and extending loans and cash grants to firms in badly hit sectors.

However, most of these phenomena have occurred in most countries and their labour market outcomes have responded in a much smoother way than in Spain. In this paper, we review the determinants of this poor performance by analysing the institutions in place, how the Spanish labour market fared in previous recessions, the specifics of the current policies to respond to Covid-19 and the challenges ahead given the new megatrends underway (digitalization, robotics and artificial intelligence (AI), platform economy, etc.). Some policy recommendations are also provided to efficiently resume post-crisis recovery. Hence, to a far greater extent than in a typical downturn, the current crisis is not simply a general slowdown in economic activity but may also mean a somewhat radical shift in the mix of economic activities at a time of accelerated technological change. This points towards the need not only to find ways of insuring workers being furloughed or losing their jobs but also for an urgent reallocation of some of these workers to other sectors that the megatrends are pushing.

The rest of the paper is organized as follows. Section 2 briefly reviews existing labour market regulations in Spain and their roles in explaining past performances in other recessions. Section 3 focuses on the effects of the current epidemics, paying particular attention to flow data among different labour market states. Section 4 provides a speculative look at the prospects of the post-Covid-19 era and of those innovations to employment and social policies that might be needed to promote growth and reduce inequalities. Section 5 concludes.

\section{Labour market institutions and past performance}

Over the past four decades, the performance of the Spanish labour market has been (and still remains) highly dysfunctional. Among its most worrying features prior to the pandemic crisis, the following stand out:

- A much higher and more volatile unemployment rate than in most developed countries (Figure 1). During the past three decades, it has reached an average of $17.3 \%$ (compared to $7.6 \%$ in the EU-8 and $5.2 \%$ in the US), while only in two instances (2006-2007) converged to the average unemployment rate of the EU-8 $(8 \%)$. Its standard deviation doubles (triples) that of the US (EU-8). In 12 of the past 30 years, it has exceeded $20 \%$, a dramatic figure by all means, that may be reached again by the end of 2020. The bulk of the policies aimed at fighting unemployment have been mostly devoted to passive measures (unemployment insurance), with a low efficacy of active labour market policies, which has led, among other factors, to high structural unemployment. Weaknesses of these policies at dealing with job reallocation were most apparent during the early 1980s, when an intense job reshuffling process in manufacturing took place in preparation for membership in the EU, and after the Great Recession, when the bursting of a housing bubble led to a downsizing of the construction sector. 


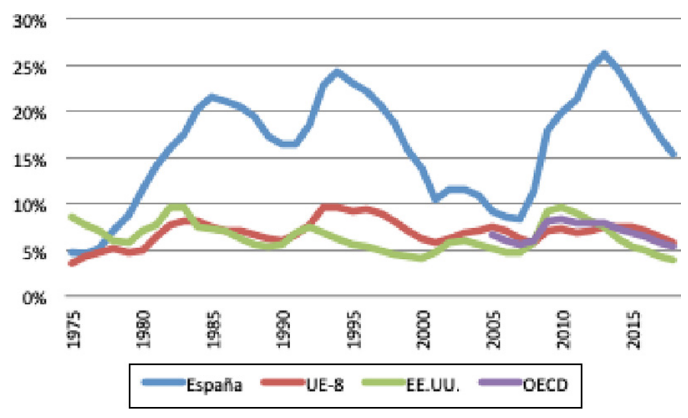

Source: OECD
Spanish labour market

Figure 1. Unemployment rates

- A high degree of dualism (Figure 2), with a large share of temporary contracts (TC) among employees (33\% before the Great Recession and $25 \%$ by 2019, after the destruction of $1.8 \mathrm{~m}$ of temporary jobs during the previous crisis, out of which only $1.2 \mathrm{~m}$ were subsequently recovered). The rate of temporary work far exceeds those in other EU countries with a similar weight of sectors where TC is in high demand (agriculture, hospitality, construction, tourism, etc.). This excess of TC was mainly because of the gap in employment protection legislation (EPL) between workers under open-ended contracts (OEC) and those with TC, both in terms of statutory severance pay and legal uncertainty (red-tape costs) [1]. Faced with this gap, the role of TC as a screening device for workers" skills has given way to a simple labour cost-reduction device. Despite a long string of reforms (52 in total), all these conditions have not yet been met in Spain. Employers carry out $90 \%$ of monthly hiring through TC, and Spain is the country with the highest transition rate from temporary employment to unemployment and the lowest conversion rate from TC to OEC (less than 10\%) within the EU (Bentolila et al., 2020). Were wages flexible enough and workers risk neutral, most of these costs could be passed onto wages (leading to steeper wage-tenure profiles) with neutral effects on employment (Lazear, 1990).

- Lack of wage flexibility (mostly before the 2012 labour market reform). Both during the collapse of the European Monetary System in the first half of the 1990s and the Great Recession in the late 2000s, labour market adjustments in Spain have

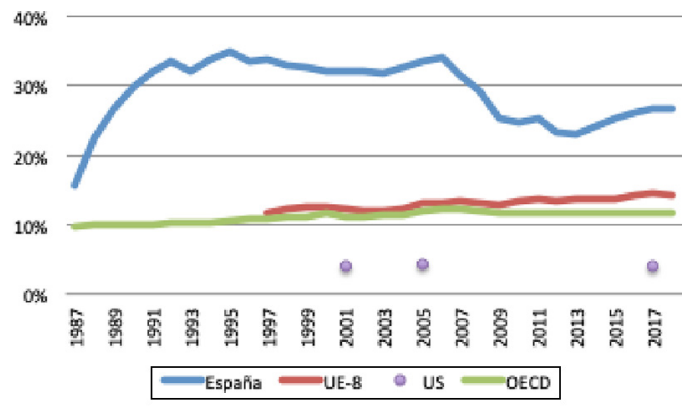

Source: OECD

Figure 2. Temporary work rates 
AEA

29,85

\section{4}

operated through quantities rather than prices (the unemployment rate skyrocketed to $24 \%$ and $27 \%$, respectively, in these two downturns). This was because of the prevalent sectoral/province collective bargaining system at the time, inherited from the democratic transition period (Dolado, 2017). On the one hand, wage setting at the sector level gives rise to higher pressure on wage mark-ups over nominal productivity, compared to bargaining at the firm or nationwide levels (Calmfors and Driffill, 1998). On the other hand, given that workers under TC are a marginal group of voters in trade union elections, unions favoured the interests of permanent workers. The underlying rationale for this insider-outsider behaviour was the expectation that, in the face of rigid wages, firms would implement workforce adjustments mainly though the non-renewal of $\mathrm{TCs}$, being a much cheaper procedure than individual or collective dismissals of workers under OEC. Given that, due to their less-stable contacts, temporary workers had typically lower qualifications and received less on-the-job training than workers under OEC, wage differentials have been growing (Cabrales et al., 2017).

- Labour market institutions are also partly behind the poor productivity dynamics in Spain over the past decades, with negative Total Factor Productivity (TFP) growth rates for much of the 2000s. In relation to other countries, the productivity gap between business start-ups and established firms is higher, while fastest-growing firms are not necessarily the most productive (Moral-Benito et al., 2019). These two features result in a large number of small-sized unproductive firms (with $40 \%$ lower TFP than in the EU-5) with lower survival probability than a relatively small group of large and more efficient corporations, but less so than in EU-5 (10\%). On top of innovation capacity, sectoral composition, access to funding and product market regulations, the most relevant factor behind productivity is the scarcity of human capital. In this respect, the excessive labour market segmentation in Spain does not facilitate on-the-job training of temporary workers, as employers abstain from investing on them given their short-term job tenures. The EPL gap creates an incentive to hire this type of workers in sectors where TC can be widely used. Before the Great Recession, this led to the upsurge of the construction and ancillary sectors as the engines of the Spanish economy. The push from these sectors led to strong wage growth in less-skilled occupations that raised the school dropout rate exacerbating low productivity (Bonhomme and Hospido, 2017). During the subsequent slump, their inflows to unemployment were massive, making long-term unemployment a chronic phenomenon (62\% of the unemployed in 2014 and 36\% nowadays).

\subsection{The labour market reforms in 2012 and the recovery before the pandemic}

Under the strong pressure of both the employment collapse and the skyrocketing unemployment rate brought about by the global financial and sovereign debt crises, the main goal of the 2012 labour market reform was to achieve greater internal flexibility, both in terms of wages and working conditions. The new approved regulations (easing firms' opt-outs from sectoral agreements, fostering firm-level wage bargaining, limiting ultraactivity clauses, facilitating part-time employment, etc.) led to rising firms' bargaining power relative to workers, with the goal of reducing labour costs and promoting exports as a way out towards recovery (Almunia et al., 2020).

With the benefit of hindsight, it seems that most of the objectives of this reform were successful, certainly helped by the favourable change in international macro-economic 
conditions and the overall recovery of the worldwide economy. The noticeable exception of the intensive use of TC (especially in the public sector), which remained at $25 \%$ of all employees. Over 2013-2019 almost $3.0 \mathrm{~m}$ jobs were created while unemployment decreased by 3.3 million from its peak in 2014 [2]. Hospitality and tourism took over construction as the engines of the Spanish economy, again two low-productivity sectors with massive use of TC [3]. The wage devaluation process was not due to a lower growth of bargained wages for stayers, which remained stable in real terms, but to large wage cuts in entry wages, especially for temporary workers with low qualifications and a sharp reduction in effective paid hours (Figure 3). Thus, the counterpart of this recovery was a strong decline in the labour share in gross domestic product (GDP), in parallel with higher degrees of precariousness and labour poverty (working poor). Finally, despite a substantial reduction in the EPL gap, another salient feature of the recovery phase has been the sharp reduction in the duration of TC ( $40 \%$ last less than a month and $25 \%$ less than a week), which also affected $\mathrm{PC}$ contracts (with a strong rise in dismissals for economic reasons after the first two years of seniority) [4].

\section{The Covid-19 crisis}

The pandemic caught the Spanish economy with symptoms of economic slowdown and a lesser push from the foreign sector due to the trade war between China and the US. A central feature of all recessions is a positive co-movement among output, hours worked, consumption and investment. In this respect, the COVID-19 recession (Great Contagion) is not unique.

Most macro models of the Great Contagion that integrate the epidemiological (SIR) process take for granted that the virus generated both negative demand and supply shocks by reducing consumption and the supply of labour, respectively, shifts that were needed to reduce the risks of infection (Eichenbaum et al., 2020; Kaplan et al., 2020). What type of shock dominates depends on whether prices/wages are fully flexible (neoclassical Real Business Cycle model) or sticky (new Keynesian model). Typically, the neoclassical model (where output is supply-determined) fails to generate a positive co-movement between investment and consumption. In effect, suppose that people become infected through social

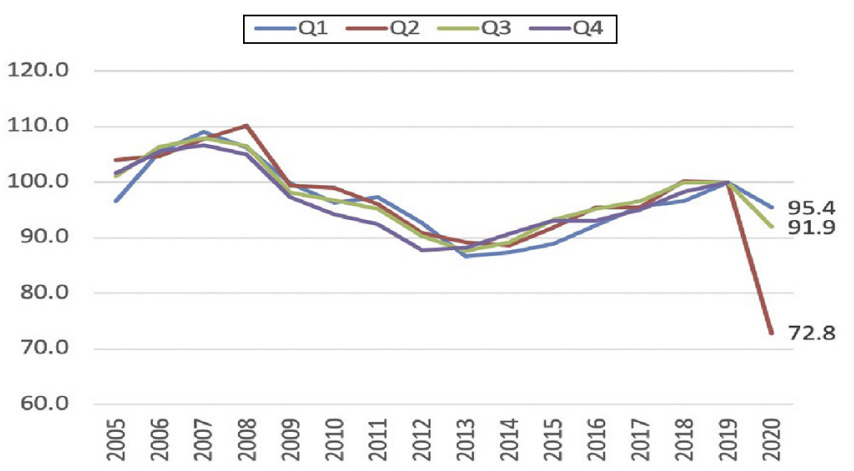

Notes: Working hours include moonlighting. Missing values have been replaced by the average working hours of professional status, economic activity and occupational cells

Source: EPA

Spanish labour market

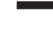


AEA 29,85

consumption activities but not by working. This would lead to a large drop in consumption and a rise in investment, as individuals wish to consume less now (save more) and more once the infection is controlled, and also want to smooth hours worked over time. By building up the capital stock, both objectives can be accomplished. Next, suppose that people only become infected by working. Then, due to consumption smoothing in the face of transitory falls in income, the epidemic leads to a small decline in consumption but to a large fall in employment, investment and output. These mechanisms operate similarly under sticky prices (where output is demand-determined), but in this case, the downward shift in working hours dominates the fall in consumption, as the real wage falls by more, lowering the reward of being exposed to the virus.

The fact that consumption and investment have plummeted in Spain (reductions of $-6.8 \%$ and $12.3 \%$, respectively, relative to 2019 , while working hours so far has fallen by about 6.2 pp.) and a strong deflation has not happened yet, points to a balanced combination of both shocks in a sticky-price environment.

Although it is still too early to reach definitive conclusions, three-quarters of data on the effects of the pandemic indicate that past adjustment patterns could be repeated. So far, the job declines in jobs under TC and OEC have reached, respectively, $11.6 \%$ and $1.9 \%$ since 2019Q4. However, in labour market terms, the main difference during the current slump and the previous one has been the use of furlough/short-time working options [Short-time Work (STW), Expediente de Regulación de Empleo Temporal (ERTEs) in Spanish] by employers to reduce costs in the face of slackened demand for their products or services. In contrast to the Great Recession where the shock on real estate was of a permanent nature, these schemes can now save jobs and many employees would prefer to keep their jobs, even if the result is a temporary pay loss.

The key dimension of heterogeneity for economic exposure to the pandemic is occupation. Workers in occupations that both require social interaction, and have little flexibility to work remotely (such as waiters, hairdressers and dentists), have experienced especially large drops in their earnings. In contrast, the earnings of workers in those occupations that do not require social interactions, and have high flexibility to telework (such as lawyers, academics and finance professionals) have been left relatively unscathed. Whether these different labour market experiences translate into persistent differences in economic welfare depends on households' financial vulnerability. The evidence in this respect is that there is a strong positive correlation between economic exposure to the pandemic and financial vulnerability suggesting that the effects of the pandemic have been extremely unequal across the population (Glover et al., 2020). There is thus, a great deal of scope for economic and health policies, with appropriate patterns of redistribution, to both contain the virus and mitigate the economic losses of the most affected households.

\subsection{Employment policies during the Covid-19 crisis}

The pandemic has had a large impact on the labour market performance, both in aggregate stocks and in worker and job flows. Figures 4 and 5 display changes of these indicators using labour force survey data Encuesta de Población Activa (EPA), in millions of people and in quarterly rates, respectively.

Three remarkable facts stand out:

- Employment has fallen by 2.45 million people (14.2\%) in two quarters (between 2019Q4 and 2020Q2), while it took 17 quarters to achieve such a crash (between 2007Q3 and 2011Q4) in the financial crisis. According to the latest released figures in $2020 \mathrm{Q} 3$, slightly more than half $(52.5 \%)$ of these job losses have been recovered, but the cumulated loss relative to 2019 still reaches $5.9 \%$. 


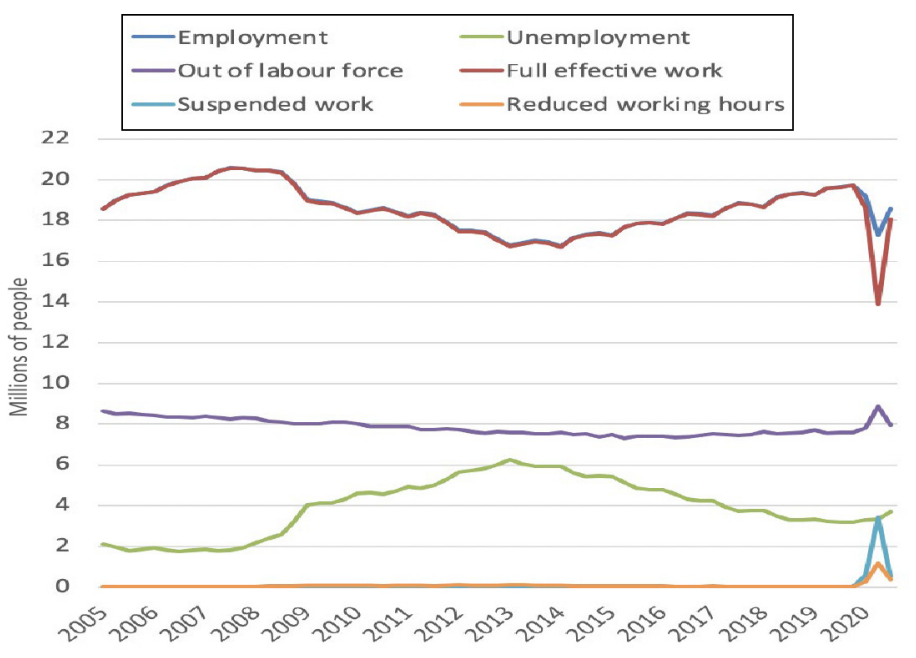

Spanish labour market

Source: EPA

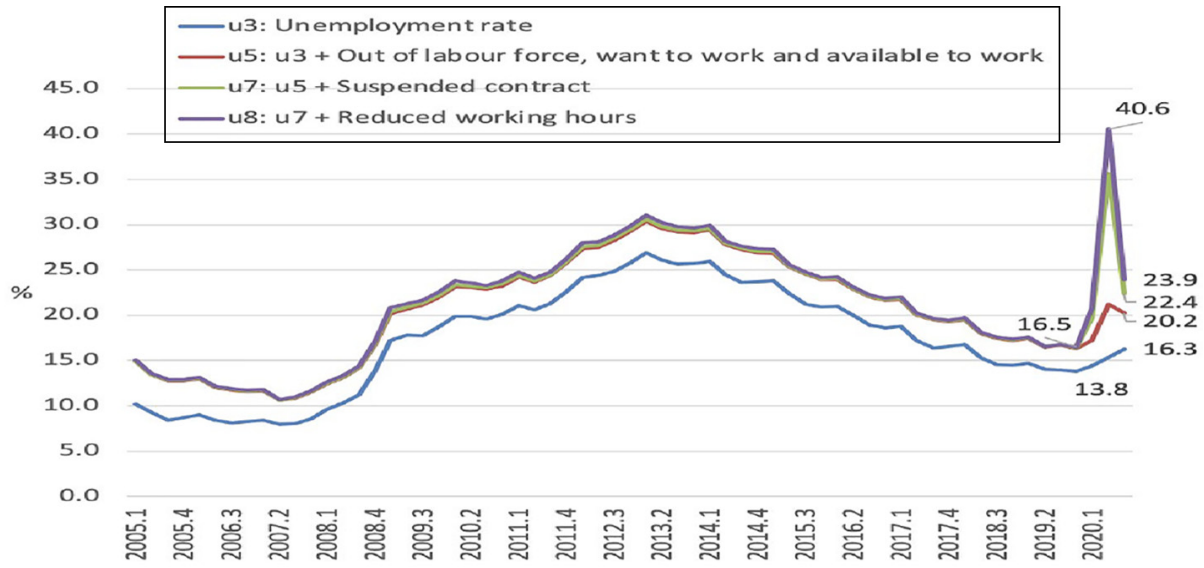

Source: EPA

Figure 5.

Alternative measures of labour underutilization (2005Q1-2020Q3)

- Unlike the Great Recession, employment protection mechanisms have been activated involving STW programmes such as the Temporary Employment Regulation scheme and those that allow firms to transitorily suspend contracts or reduce the working time of part or all of their employees, the so-called ERTEs. In addition, the Extraordinary Benefits of Termination of Activity programme for the self-employed (and also for discontinuous OECEs) allowed these workers to remain employed and keep their status as Social Security affiliates.

According to social security data, in April 2020, workers protected by ERTEs reached a maximum of 3.4 million ( $24.2 \%$ of the workers affiliated to the General Regime) and 
AEA 29,85
1.5 million self-employed workers attended the cessation of activity (46.7\% of those affiliated to the special regime for self-employed workers at the end of May 2020). By September 2020, ERTEs covered 729,000 workers. The data on benefits reaches about 4 million initial registrations because of suspension ERTEs, and 900,000 in suspension of contracts.

According to EPA, on average, about 4.6 million people in 2020-Q2 were enrolled in ERTEs or partial unemployment. If this figure is added to the net job destruction, the number of people who have actually worked (full effective work, FEW) decreased by 5.9 million (29.7\% less) in 2020Q2 relative to 2019Q4. In 2020-Q3 there were still 1.7 million fewer people than in 2019 Q2 (8.5\% less).

- There has been a labour force reduction. The number of inactive people between 16 and 64 years of age increased by about 1.3 million $(16.9 \%)$ compared to 2019Q4, while in 2020Q3, this figure was still 5.1\% lower than 2019. This fall initially slowed down the rise in the number of unemployed, although in 2020Q3 these were still $16.3 \%$ more than in $2019 \mathrm{Q} 4$.

The above-mentioned features make the unemployment rate not a good indicator of the underutilization of labour during this pandemic. The official unemployment rate barely increased by 2.5 pp. since 2019Q4, due to both the fall in activity (and therefore, in the number of unemployed) and the STW schemes. However, following the methodology of the US Bureau of Labour Statistics, Figure 5 displays different alternative indicators to the conventional unemployment rate. In addition to the standard definition according to the International Labour Organization conventions, the following groups are added to the unemployed, namely, those who do not search (due to the lockdowns) but are available to join a job (u4), workers covered by ERTE for suspension of contract (u5) and those with reduced working hours due to ERTEs (u6). This broader unemployment rate reached $40.6 \%$ in 2020Q2, falling to $23.9 \%$ in 2020Q3, still 6.4 pp. higher than in 2019Q4.

Better understanding of the channels through which these outstanding variations in labour market slack have occurred requires a dynamic analysis looking at worker and job flows.

\subsection{Transitions from employment to non-employment during the first wave of the Covid-19 crisis}

Despite the use of employment protection schemes, outflows from employment (E) to nonemployment (UI, unemployment and inactivity lumped together), denoted employment to unemployment inflows (EUI), reached historical highs in 2020Q2, practically doubling those in 2019Q2 and exceeding by far those during the Great Recession (Figure 6).

Consensus forecasts had anticipated that Spain would suffer a greater relative impact from the lockdown and social distancing rules than the other EU/Organisation for Economic Co-operation and Development (OECD) member countries. This is because of its peculiar sectoral and occupational structure, the characteristics of its working-age population (e.g. lower educational attainments and skills for teleworking) and a large fraction of small firms.

Cross-country GDP and employment figures for 2020Q2 seemingly confirm the diagnosis of these initial predictions. Figure 7 shows the relationship between the year-to-year rise in quarterly employment exit rates in 2002Q2 for several OECD countries and four alternative indicators, namely, GDP growth (Panel a), an index of workers' ability to cope with lockdowns (b), STW coverage (c) and previous job exit rates (d). Spain ranks as an outlier in each chart. Firstly, in Panel a, there is no clear correlation between the decline in output and the job destruction flows during the lockdown period. However, Spain leads the reduction in 


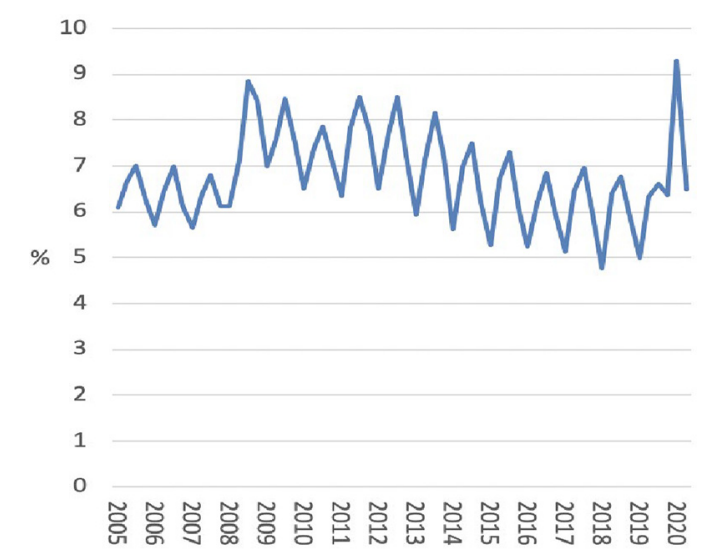

Note: (*) \% Quarterly transitions from employment to non-employment

Source: EPA
Spanish labour market

Figure 6.

Employment outflow rate (2005Q1-2020Q3)

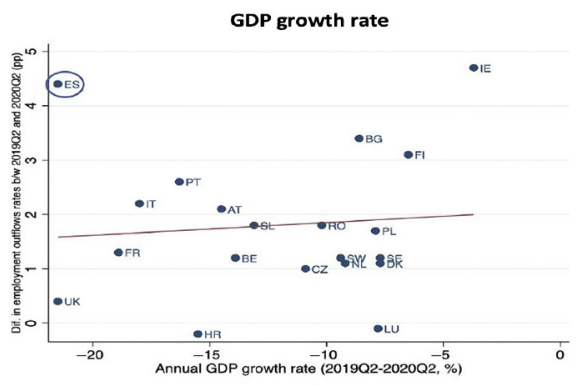

(a)

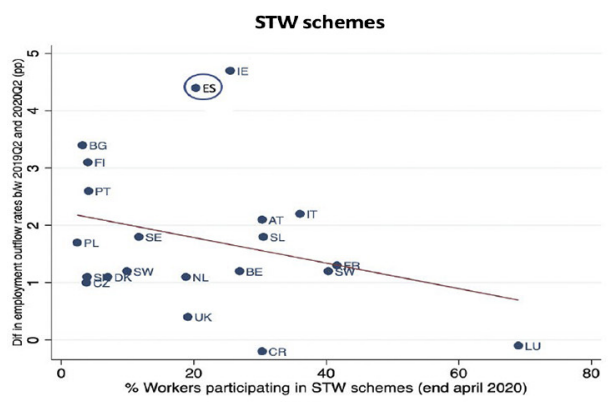

(c)

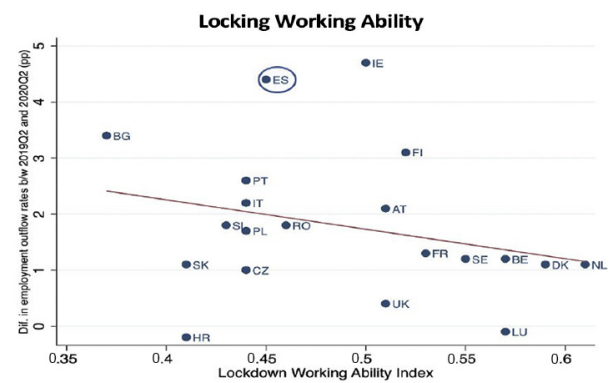

(b)

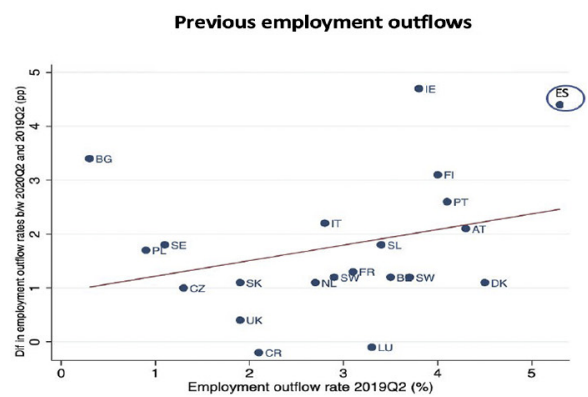

(d)
Figure 7.

Correlations between employment outflows and several indicators
Sources: Eurostar (GDP and Employment Outflow rates), Lockdown Working Ability Index in Palomino et al. (2020), Workers participating in STW schemes computed for 2020Q2 with data from Müller and Schulten (2020) 
AEA 29,85

Figure 8.

Employment and unemployment outflow rates to inactivity both indicators. Secondly, Panel b shows that Spain experienced much higher job destruction than other countries with similar or even lower indicators of teleworking adaptability. On the contrary, Panel c shows that there is a clear correlation between the coverage rates of STW schemes and the employment to non-employment outflow. Finally, Panel d shows the correlation between this increase in outflows in 2002Q2 and their lagged value in the same quarter of 2019.

Spain has reached a much lower coverage rate for STWs than Austria, France, Italy or Switzerland, albeit much higher than Portugal. Yet, this comparison is not enough to explain such a striking difference in the increase of job shedding. As already discussed, the insight for this poor performance is the high rate of temporary work in Spain, which explains why quarterly transitions from employment to unemployment (EU) are substantially higher than elsewhere. In fact, during the first two weeks of the Alarm State, there was massive job destruction, with the termination of TC accounting for more than $75 \%$ of such job losses.

In sum, regardless of Spain being a candidate for a greater collapse in GDP than elsewhere, due to the large weight of sectors badly hit by the crisis, its much larger EUI and EU flow rates are due to the precariousness of industrial relations, which, in turn, limited the even wider use of STW schemes.

\subsection{Flows from employment to inactivity}

As explained above, a peculiar fact of this pandemic has been the fall in labour force participation rates. Figure 8 shows the EU and UI transition rates, distinguishing between individuals who do not seek employment but wish to work and those who do not. The fact is that the rules of confinement, and probably the slowdown in hiring (and therefore, the discouragement effect) have greatly altered the job search processes. As can be seen, the fall in the workforce was driven by the increase in transitions from unemployment or employment to the group of people who are not looking for a job but wish to work.

\subsection{The slowdown in hiring and the rise of long-term unemployment}

The net job destruction during the pandemic has been driven first by the increasing employment outflows in the first weeks of the State of Alarm, and then by the hiring freeze, which led to a reduction in employment inflows and unemployment exits. Figure 9 displays these flows, using monthly data on affiliation to the social security registered

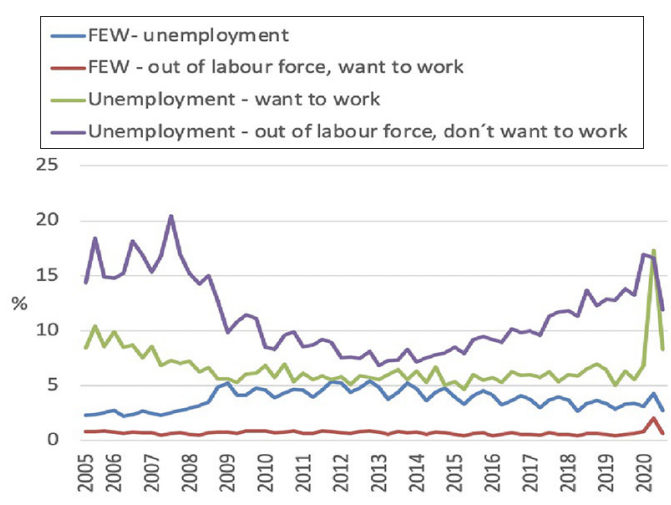

Source: EPA 

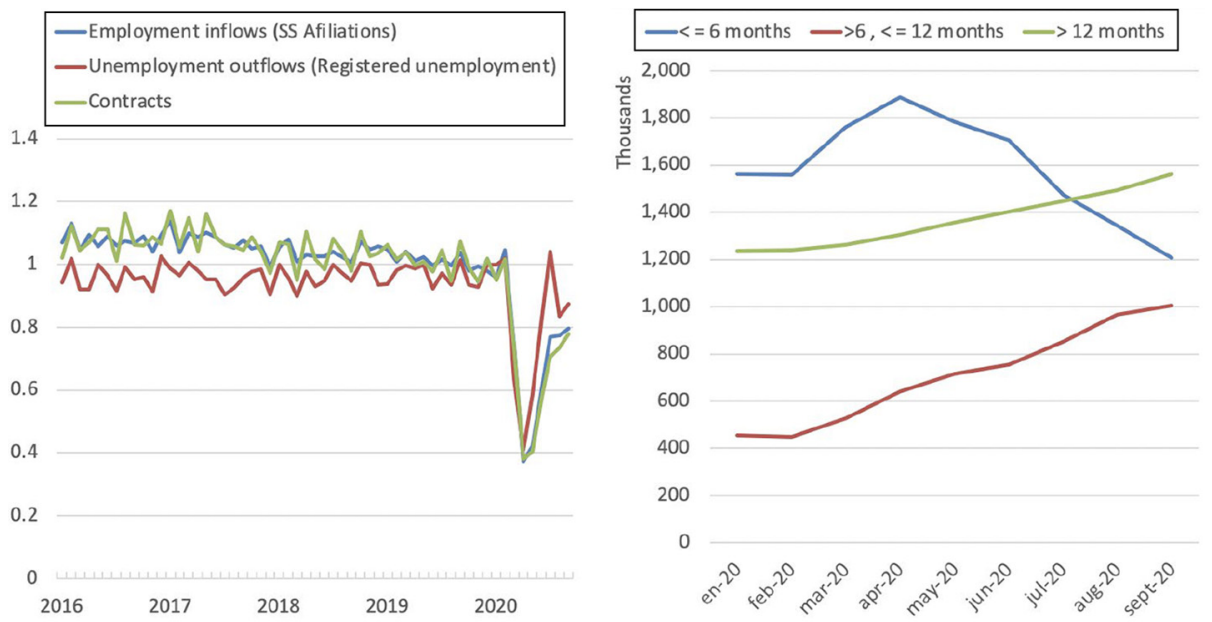

Source: Social Security Register and SEPE
Spanish labour market

\section{1}

Figure 9.

Employment inflows, unemployment outflows, number of contracts in 2002Q2 (relative to 2019Q2) and unemployment duration (Jan-Sept

2020)

unemployment. As can be inspected, both the number of contracts and these flows fell by $60 \%$ relative to those registered in 2019 . Six months later, they have slightly recovered, being $80 \%$ of those registered before the crisis. Consequently, unemployment duration has progressively scaled up. In particular, from the moment the intense job- destruction process was stopped, short-term unemployment began to fall, while long-term unemployment increased. Using data from MCVL (2018), Felgueroso et al. (2020) show that, prior to 2020, about 1.7 million unemployed workers found a job during the equivalent first two months of the State of Alarm. Note that the second quarter is usually the quarter where UE flows are greater.

\subsection{Outflows of the STW schemes}

The use of employment protection schemes in Spain has been less intense than e.g. in France, due to the disproportionate layoffs of temporary workers. Prior to the pandemic, $60 \%$ of the TC registered in Spain were rehiring contracts, that is, temporary layoffs. Therefore, the mixed strategy followed during the pandemic can be interpreted as a combination of the European STW schemes and the American temporary layoffs. One of the questions that will probably generate more research in the coming years is which of these two solutions has been more effective in recovering employment. That is, whether STW schemes, despite a priori providing a safer guarantee of job protection, can slow down the relocation process during the recovery compared to temporary layoffs. The fact that Spain has used a mixed solution makes it a nice testing ground to assess this issue.

The data available for 2020Q3 allows us to address this question, albeit in a descriptive, and therefore, only intuitive way. Using EPA, Table 1 displays the quarterly transitions of workers covered by ERTEs to alternative labour market states. About $59.0 \%$ and $66.0 \%$ of private sector employees covered by ERTE of suspension of employment in 2020Q1 and Q2, respectively, returned to full-time jobs in their previous firms, while less than $2 \%$ moved to another company. However, after FEW, the second-largest transitions are to another type of ERTE, implying a reduction in working hours of $15.3 \%$ and $11.8 \%$ in 2020 Q2 and Q3. 
AEA

29,85

32

Table 1.

STW schemes outflows (private sector employees)
Finally, $16.9 \%$ and $15.2 \%$, respectively, lost or quit their jobs, becoming unemployed or inactive.

Figure 10, in turn, shows the UIE transitions among those employees who lost their jobs job between 2020Q1 and Q2, depending on whether they were recalled to the same firm or not. As can be seen, the return of these workers to employment is momentarily much lower than the corresponding rates for workers under ERTE. However, to make a more accurate analysis it is necessary to control for other factors.

To do so, a more detailed empirical analysis of the above phenomena is provided through the estimation of three multinomial logits modelling transitions from: employment, ERTEs and unemployment or of those inactive willing and available to work. Specifically, we analyse first the transitions from employment to each of the following different states, namely, effective work, ERTE with contract suspension, ERTE with reduction of working hours, unemployment or inactivity (distinguishing between those willing to work or not) between 2020Q1 and Q2 and, separately, between the corresponding first and second

\begin{tabular}{|c|c|c|c|c|}
\hline \multirow[b]{3}{*}{ Transitions to } & \multicolumn{4}{|c|}{ Transitions from } \\
\hline & \multicolumn{2}{|c|}{ STW-suspended work } & \multicolumn{2}{|c|}{ STW-reduced working hours } \\
\hline & $\underline{\mathrm{Q} 2}$ & $\underline{\mathrm{Q} 3}$ & $\underline{\mathrm{Q} 2}$ & $\underline{\mathrm{Q} 3}$ \\
\hline FEW (same firm) & 58.7 & 66.4 & 68.9 & 80.8 \\
\hline FEW (different firm) & 1.9 & 1.9 & 1.4 & 0.8 \\
\hline Unemployment & 7.4 & 5.5 & 9.1 & 2.6 \\
\hline STW-suspended work & 15.3 & 11.8 & 5.2 & 0.8 \\
\hline SRW: reduced working hours & 7.2 & 4.6 & 9.2 & 13.0 \\
\hline Out of labour force (want to work) & 3.2 & 3.3 & 2.2 & 0.9 \\
\hline Out of labour force (do not want to work) & 6.3 & 6.4 & 3.9 & 1.1 \\
\hline
\end{tabular}

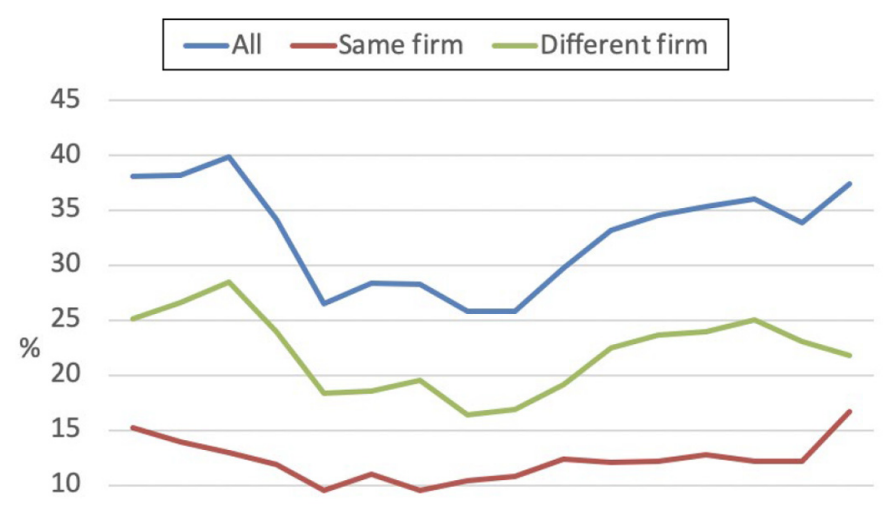

5

Figure 10.

Non-employment outflows to employment
0

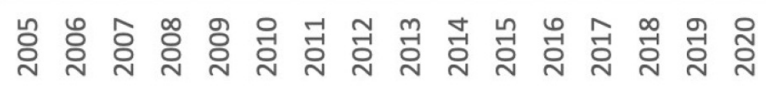

Source: Social Security Register and SEPE 
quarters in 2016-2019 (Table 2). Then, we analyse transitions from private sector employees under ERTE with suspended contracts to the above-mentioned states between 200Q2 and Q3 (applying the same distinction as before to effective work) (Table 3). Finally, the third market model is intended to estimate the determinants of the transitions from unemployment or inactivity (for those willing and available to work) to employment in the same firm o in a different one, between 200Q2 and Q3, as well as between these quarters prior to the crisis, 2016-2019 (Table 4). We report estimates of the relative risk ratios (RRR) for variables such as gender, age, educational level and type of contract in the two first models, and for time elapsed since the last job in the third model [5]. In all specifications, the referent group is to remain in the initial state.

The results from comparing transitions by gender during the first wave of the Covid-19 crisis indicate no statistically significant gender gaps between remaining in an effective work state and transitioning to a situation of ERTE or unemployment; yet, there is a greater propensity of women to transit into inactivity. Moreover, the gender difference in this transition is lower than in these same quarters of previous years, as a substantial fraction of men also stopped their job search. Likewise, the transitions from ERTE in the following quarter (Q3) do not differ by gender though, before the pandemic, unemployed women were less likely to find jobs in a different company than the firm where they were working before losing their jobs.

\begin{tabular}{|c|c|c|c|c|c|c|}
\hline & $\begin{array}{l}\text { Ris } \\
\text { STW suspended } \\
\text { work }\end{array}$ & $\begin{array}{l}\text { s relative ratios } \\
\text { STW reduced } \\
\text { working hours }\end{array}$ & - multinomial logi & $\begin{array}{l}\text { Inactivity, willing } \\
\text { to work }\end{array}$ & $\begin{array}{l}\text { Inactivity, does } \\
\text { not want to work }\end{array}$ & \\
\hline \multicolumn{7}{|l|}{ Gender } \\
\hline \multicolumn{7}{|l|}{ Women/men } \\
\hline 2020 & 1.053 & 1.029 & 1.054 & $1.312^{* * * *}$ & $1.385^{* * * *}$ & \\
\hline 2016-2019 & 1.013 & 0.730 & 1.038 & $1.753 * * *$ & $1.392^{* * * *}$ & \\
\hline \multicolumn{7}{|l|}{ Age } \\
\hline \multicolumn{7}{|l|}{$16-29 / 30-44$} \\
\hline 2020 & $1.409 * * *$ & $1.196 * *$ & $1.292 * * *$ & 1.036 & $1.801 * * *$ & \\
\hline 2016-2019 & 1.009 & 0.620 & 1.064 & $1.205^{*}$ & $2.326^{* * * *}$ & \\
\hline \multicolumn{7}{|l|}{$45-64 / 30-44$} \\
\hline 2020 & $1.0681 * *$ & $1.090 *$ & 1.012 & 1.043 & $1.224 * * * *$ & \\
\hline 2016-2019 & $1.747 * *$ & 1.133 & 1.030 & $1.353 * * *$ & 1.657 **** & \\
\hline \multicolumn{7}{|c|}{ Educational attainment } \\
\hline \multicolumn{7}{|c|}{ Low/medium } \\
\hline 2020 & 0.991 & $0.798 * * * *$ & $1.245^{* * * *}$ & 1.102 & 0.998 & \\
\hline 2016-2019 & 0.987 & 1.383 & $1.130 * * *$ & $1.564 * * *$ & $1.090^{*}$ & \\
\hline \multicolumn{7}{|l|}{ High/medium } \\
\hline 2020 & $0.799 * * *$ & 0.965 & 0.975 & $0.652 * * *$ & $0.605^{* * * *}$ & \\
\hline 2016-2019 & 0.731 & $1.523^{*}$ & $0.918^{*}$ & 0.928 & $0.597^{* * * *}$ & \\
\hline \multicolumn{7}{|c|}{ Type of contract } \\
\hline \multicolumn{7}{|c|}{ Fixed-term/permanent } \\
\hline 2020 & 1.070 & $0.854^{*}$ & $3.683 * * *$ & $3.473 * * *$ & $2.496 * * *$ & \\
\hline 2016-2019 & 1.018 & 1.211 & $4.826^{* * * *}$ & $5.459 * * *$ & $2.190 * * *$ & Table 2. \\
\hline \multicolumn{7}{|c|}{$\begin{array}{l}\text { Notes: }(*) \text { Additional control variables: part-time work, job tenure, employment status, occupation } \begin{array}{r}\text { Quarterly transitions } \\
\text { (CNO11-1 digit), economic activity (CNAE09-1 digit), CCAA, year; } * * * * \text { and } * * * \text { mean statistical significance } \\
\text { at } 10 \%, 5 \% \text { and } 1 \% \text { levels, respectively }\end{array} \\
\text { work, 2020 Q1-Q2 }(*)\end{array}$} \\
\hline
\end{tabular}


Risk relative ratios - multinomial logit model

STW

Full effective Full effective reduced

work. Same work. Dif. working

firm firm hours Unemployment

Inactivity, Inactivity, want does not to work want to work

\section{4}

Gender

Women/men

0.861

0.854

0.844

0.913

0.861

0.793

Age

$16-29 / 30-44$

1.115

$1.647^{*}$

0.899

1.127

1.146

1.060

1.231

45-64/30-44

0.872

0.792

1.038

0.794

$1.580^{* * *}$

$0.476 * * *$

1.275

Low/medium

1.132

0.854

$0.934 \quad 0.975$

0.950

0.742

Table 3.

Quarterly transitions from suspended contract, private sector employees, 2020Q2-2020Q3

\section{Type of contract}

Fixed-term/permanent
$2.946 * * *$

$0.503^{*}$

$3.729 * * *$

$3.186^{* * * *}$

$2.047 * * *$

Notes: (*) Additional control variables: part-time work, job tenure, occupation (CNO11-1 digit), economic activity (CNAE09-1 digit), CCAA; *, ** and ***mean statistical significance at 10\%, 5\% and 1\% levels, respectively

As shown in Tables 2 to 4 above, employees with a lower education attainment (less than compulsory secondary education) have exited from employment to a lesser extent towards ERTE with reduced working hours, while they have existed to unemployment. However, they are more likely to return to employment from the ERTE in different companies than those with middle educational levels. The latter, in turn, have a greater probability of transitioning from employment to inactivity (between Q1 and Q2, Table 2) and from ERTE to inactivity (between Q2 and Q3, Table 3), as well as a lower probability of returning to employment from non-employment (between Q2 and Q3, Table 4) than those with college.

With respect to type of contract, workers under TC exhibit a lower propensity to go from employment to ERTEs with reduced working hours than those under OEC, and a greater propensity to transit to unemployment and inactivity during the State of Alarm. Likewise, between Q2 and Q3, they have had a greater probability of transitioning to employment in another company, unemployment and inactivity.

Finally, the long-term unemployed have a lower relative propensity to return to employment during the crisis than in the same quarters of previous years. By contrast, those people who lost their job in the first months of the pandemic have a higher relative probability to return to their previous firm than those who became unemployed before the crisis.

In short, the previous transitions analysis (expanding the potential working states with ERTEs and inactivity with the willingness and availability to work) shows that the impact that this crisis on the Spanish labour market follows a similar pattern to those in the previous downturns. In effect, the most vulnerable workers have been worst hit: young people, women, people with a lower educational level and temporary workers. For the moment, the return of people in ERTE to employment seems to have been greater and faster than for those laid off at the beginning of the crisis.

As regard age, young people turn out also to be the most affected in the first months of the pandemic, with greater transitions from employment to other states, including ERTE, 
Gender

Women/men

2020

2016-2019

Age

$16-29 / 30-44$

2020

2016-2019

45-64/30-44

2020

2016-2019

Educational attainment

Low/medium

2020

2016-2019

High/medium

2020

2016-2019

Previous job/no previous job

Time since last job

$>=4,<12 \mathrm{~m} . /<4 \mathrm{~m}$.

2020

2016-2019

$>=12 \mathrm{~m} . /<4 \mathrm{~m}$.

2020

2016-2019

Notes: (*) Additional control variables: part-time work, job tenure, employment status in previous job, occupation in previous job (CNO11-1 digit), registration at public employment office, recipient of unemployment benefits, CCAA and year effects; * ** and ***mean statistical significance at $10 \%, 5 \%$ and $1 \%$ levels, respectively

$\begin{array}{ll}1.078 & 0.767^{* * * *} \\ 0.987 & 0.767^{* * *} \\ & \\ & \\ 0.936 & 1.148 \\ 0.921 & 1.247^{* * * *} \\ 0.895 & 0.704^{* * * *} \\ 0.850^{* * * *} & 0.601^{* * *}\end{array}$

1.006

$0.946 \quad 0.852^{* * * *}$

$1.250 * * * 1.290 * * *$

$1.154^{* * *} \quad 1.134 * * *$

$4.015^{* * * *} \quad 2.034^{* * * *}$

$4.015^{* * * *} \quad 2.034^{* * * *}$

$5.402^{* * * *} \quad 1.407^{* * * *}$

$2.292^{* * * *} \quad 1.584^{* * * *}$

$1.400^{* * * *} \quad 1.245^{* * * *}$

$0.258^{* * * *} \quad 0.481^{* * * *}$

$0.264 * * * \quad 0.731^{* * * *}$

Table 4.

Quarterly transitions from unemployment and inactivity (does not want to work), Q1-Q2 (*)

than middle-aged and older adults. This difference, however, vanishes in the following quarter, although it remains regarding the exit of the ERTEs to employment in different firms. In addition, as Felgueroso and De la Fuente (2020) have shown, targeted labour contracts for young people (training and internships) have been the most affected ones, reaching all-time lows.

These findings are corroborated with data from social security affiliation and registered unemployment. As shown in Figure 11, men experienced a greater reduction in employment (increase in unemployment) than women during the first weeks of the State of Alarm; yet, in the following months, men"s partial recovery of employment levels prior to the pandemic has also been faster. These patterns are similar to those observed in previous recessions.

\section{The labour market post-Covid19}

As time goes by, with the pandemic far from being fully controlled and lockdowns and other restrictions to economic activity emerging as recurrent responses to potential outbreaks during the next few years, it is becoming more likely that the Covid-19 crisis could become a structural one. We are witnessing changes in working and consumption patterns and in 
AEA

29,85

\section{6}

Figure 11.

Accumulated monthly changes in employment (social security) and unemployment (registered unemployment, SEPE) from February 2020 , by gender

business models that could remain in place. Moreover, scarring effects of the crisis, through hysteresis, should not be neglected. In addition, all these changes could suggest an acceleration of structural mega-trends already in place before the crisis - namely, digitalization, job polarization, platform jobs, robotics and superstar firms -, with the concomitant rise in inequality (Autor and Dorn, 2013; Autor et al., 2020).

As a result, the job reallocation induced by the new wave of technological changes will be intensified and extended by the economic consequences of the Covid-19 crisis. It is conceivable that, after the Great Moderation and the Great Depression, we are now entering a "The Great Reallocation" era. It will be marked by radical changes in the composition of employment, consumption and economic activity. In this context, their consequences for the performance of labour market and the implications for the design and implementation of social and employment policies would be increasingly relevant. Moreover, the required job reallocation provides an opportunity to also fight other risks (and crises) that seem likely into the future, such as the challenges associated to climate change that will have to be met by a transition to new environmentally-friendly sources of energy and production of goods and services.

Under these premises, three main questions arise when anticipating the long-run effects of the Covid-19 crisis on the labour market. One has to do with the reasons why hysteresis effects ought to be larger (or smaller) than those observed in previous recessions. Another is the duration and costs associated to the job reallocation process that seems necessary. Finally, there is the endogenous response of labour market institutions in the aftermath of the Covid-19 crisis, which, among other things, will imply a large increase in wage and earnings inequality. Many of the social and employment measures implemented in response to the crisis will stay and, together with those implemented to fight increasing inequality, they may bring a significant institutional reconfiguration of labour markets across Europe. In particular, this is more likely to happen in countries, such as Spain, with higher inequality and more dysfunctional labour market institutions.

As for hysteresis effects, there are several reasons why they should be more relevant in the aftermath of the current crisis [6]. Firstly, the number of jobs lost (or suspended through SWT schemes and furloughs) has been far higher than in previous recessions (even than in the long 2008-2014 recession). Secondly, job losses have been concentrated in the low-skill and labour-intensive segments of the labour market associated to personal services provided under "physical proximity" (hotels, restaurants, recreational activities, etc.). Thus, workers who in principle are "less re-employable" have been the most affected ones. In addition, this

Changes in SS affiliations

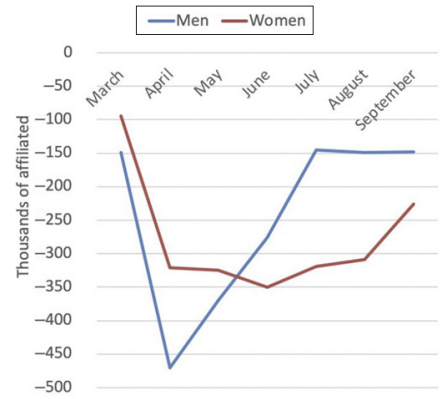

\section{Changes in registered unemployment}

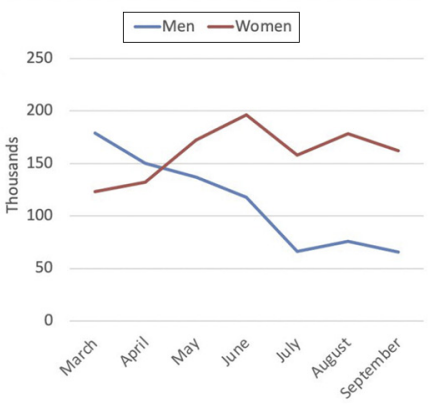

Source: Social Security Register and SEPE 
happens when new jobs created by new technologies (robotics, digitalization, teleworking and $\mathrm{AI}$ ) require skills that seem difficult to embed in those workers shed out of the personal service sectors. Moreover, the uncertainty about how these new jobs will emerge and how market new business models will use them renders active labour market policies (ALMP) (training, counselling and intermediation services) of dubious effectiveness, at least in the short-run. This concern is especially relevant when the resources available for governments to expand ALMP have been much lessened by the needs of other policies aimed at sustaining rents. Finally, the financial position of firms has also become less resilient. Hence, they will be forced to reduce costs, to repay debts and credits obtained to preserve liquidity during the pandemics and to restore balance sheets.

The confounding effects of the Covid-19 crisis and the arrival of new technologies will definitely impact on the job reallocation process that is underway. Firstly, the confinements and other social distancing measures have implied a heavy investment in working under telepresence (the so-called "teleworking"), which will remain in place determining, which jobs and workers will be recalled back once the pandemics is over. Secondly, automation and the implementation of AI algorithms provide firms with an additional margin of adjustment, namely, the substitution of jobs by machines that, unlike humans, are not affected by viruses.

This phenomenon can be illustrated by the greater impact that the pandemic is having on occupations that were already suffering from occupational polarization. Palomino et al. (2020) advanced that a rise in polarization and inequality could be expected during this crisis due to its occupational and sectoral impact. Figure 12 shows the changes in employment shares across three-digit NACE (statistical classification of economic activities) occupations since the beginning of the pandemic (vertical axis) and during the 2015-2019 period (horizontal axis). As can be seen, though the relationship is not strong, those occupations, which were more prevalent before the crisis, are the ones most affected by the pandemic and vice versa. Thus, there is some indication that the times they are-a changin "; in line with the job polarization results documented in Sebastián (2018).

Another dimension of the interaction between the Covid-19 crisis and technological changes arises from the observation that job losses have been disproportionally large

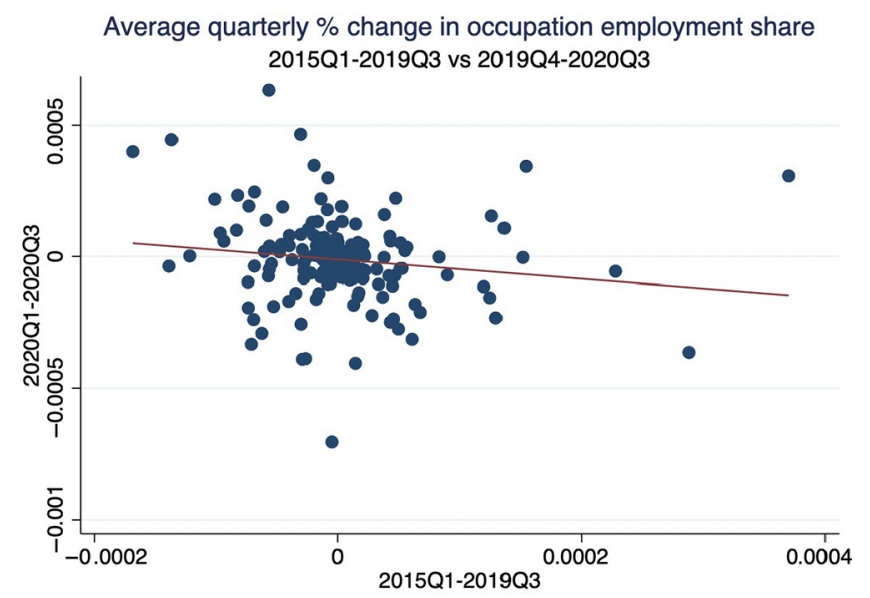

Figure 12.

Growth rates in occupational

Source: Social Security Register and SEPE 
AEA 29,85

among youth (see above). This has happened in times of profound demographic changes that are reducing the working-age population both in absolute and relative (to total population) terms. A well-known feature of recessions is the "scarring effects" that they have on the long-term careers of young workers and new cohorts entering the labour force, especially in rigid labour markets [7]. Also, the interaction of the current population ageing and technological changes (robotics and AI) have long-term negative consequences for productivity growth, through the deceleration in innovation. This deceleration has two sources. One is the combination of the aggregate constraint on resources available for investment and the trade-off between investments in innovation and automation. Another is the direct implication of an older working-age population on the success rate of innovation [8].

Finally, social and employment policies should be redesigned in light of the depth, duration and implications of the epidemic crisis. Important as well will be its the long-run consequences that (in conjunction with technological and demographic changes) are likely to occur. In some EU countries, such as Spain, the combination of "strict" EPL (relaxed by duality and the increasing prevalence of "atypical" contracts), sectoral collective bargaining with little scope for flexibility and the provision of unemployment insurance, pensions and other job-related benefits under contributory schemes, was already under heavy strains before the crisis. In the new context of heavy and costly reallocation, increasing inequalities, declining weight of labour in production (due to automation) with a falling labour share and strong pressure of population ageing on public budgets, an institutional reconfiguration of the labour market and social and employment policies seems unavoidable. New business models and diversity in work organizations will increase the pressure to reform EPL and collective bargaining. Longer periods of unemployment, lower pension entitlements associated to job losses (especially among low-skilled workers) and population ageing will also increase the demand for alternative rent protection schemes of a universal scope (the so-called Universal Basic Income complemented with in-work benefits, as in Anglo-Saxon countries, to facilitate relocation) plus a retreat of contributory benefits.

These general guidelines should be tailored to address the peculiarities of the Spanish labour market when facing strong job reallocation, brought by the pandemic crisis, in a context of declining labour shares accelerated by technological changes. Traditional employment policies coupled with the dysfunctional institutions that underly the high structural unemployment and the increasing inequalities in Spain, seem ill-suited to smooth the employment adjustment process and to raise productivity growth. In this regard, the approach under the European Social Fund (and the alike) and the EU Social Pillar (the mechanism for coordinating employment policies and fostering best-practices in the member states), which will prevail for the implementation of the EU Next Generation Fund, is bound to replicate the drawbacks of employment policies in the past. In particular, it will not provide governments with the incentives to pursue further structural reforms aimed at accelerating productivity and laying down institutions prone to high employment and reducing inequalities.

In contrast, we envisage a more comprehensive approach aimed at protecting workers negatively affected by the crisis and the rise of automation, while in parallel providing incentives for human capital investments, optimal labour supply responses to shocks and adequate use of the available public resources for employment promotion (both at the state and at the EU levels). This approach is built on the complementarities between labour market institutions and the effectiveness of employment and social policies. To exploit them, two main principles are in order, namely, the old and well-known idea of "protecting workers, not jobs", as advocated, by Blanchard and Tirole (2008); and providing workers with "resources, not so much with ideal entitlements difficult to guarantee in practice". The 
former is even more relevant under job reallocation. The latter is more convenient when work organizations, employment relationships and business models are transformed on the wave of radical technological advancements.

In the specific case of Spain, the first principle requires a radical reform of EPL to eradicate dualism, in line with the proposal of a unification of contracts (Dolado et al., 2020) coupled with pre-funded dismissal costs, akin to the Austrian Fund (Ketterman et al., 2017). In fact, the constitution of worker individual accounts, where resources from social and employment policies are accumulated under certain conditions for eligibility and disposal, should be paramount. Hence, we advocate employment policies geared towards a more intensive use of direct transfers to workers, with less regulations that are difficult to enforce and that distort both labour demand and supply.

\section{Conclusions}

We have revisited the labour market performance in Spain under a perspective influenced by the ongoing Covid-19 crisis. We conclude with some conjectures about the likely persistent effects of this crisis, when coupled with previous structural trends caused by technological changes brought by digitalization, robotics and AI. Three conclusions follow. Firstly, it has been unfortunate that the Covid-19 has hit those occupations in personal services that were the engines of employment creation after the Great Recession. These job losses have been magnified by the high prevalence of TC in these sectors. Secondly, it is conceivable that the hysteresis effects of the Covid-19 crisis are significant and that increasing job reshuffling will be a relevant feature in the next decade. Finally, under this scenario, employment and social policies need to be reconsidered. Protecting workers (and not jobs) and providing resources (not ideal entitlements) should be at the centre stage when defining their objectives and designing their instruments.

\section{Notes}

1. In a nutshell, while the dismissal of workers under OEC entail higher severance pay and could be declared unfair by labour courts, the non-renewal of TCs at their termination dates cannot be appealed and the compensation is lower (though the same as for OECs in case of dismissals). However, severance pay for unjustified dismissals was reduced to 33 days per year of service, with a maximum of 24 months' pay (previously, 45 days and 42 months) in the 2012 labour market reform, though red-tape costs remained. In cases of collective dismissal, the need for administrative authorization was eliminated. Finally, a new OEC was introduced for firms with less than 50 employees, which entailed no dismissal compensation for the first year and offered generous tax incentives. None of these measures succeeded in reducing TC.

2. Yet, compared to 2008, these figures meant about $0.6 \mathrm{~m}$ less employed and $0.4 \mathrm{~m}$. more unemployed.

3. It has been highly unfortunate that the next recession affected most negatively these sectors due to social distancing measures required to control the pandemic, as shown in Section 3.

4. Severance pay for unjustified dismissals was reduced to 33 days per year of service, with a maximum of 24 months' pay (previously, 45 days and 42 months). In cases of collective dismissal, the need for administrative authorization was eliminated. Finally, a new OEC was introduced for firms with less than 50 employees, which entailed no dismissal compensation for the first year and offered generous tax incentives.

5. The RRR of a coefficient indicates how the risk of the outcome falling in the comparison group compared to the risk of the outcome falling in the referent group changes with the variable in question. An RRR $>1(<1)$ points that the risk of the outcome falling in a specific group relative to the baseline increases (decreases) as the variable increases. 
AEA 29,85

6. For a recent survey on the theory, empirics and policy implications of hysteresis and its consequences on short-run and long-run economic fluctuations, Cerra, Fatás and Saxena (2020).

7. See Cocks and Ghilleri (2016).

8. For a general equilibrium analysis of the interactions of demographic and technological changes, Basso and Jimeno (2020). For empirical evidence on the implications of population ageing for innovation see Lazear et al. (2014) and Aksoy et al. (2019).

\section{References}

Aksoy, Y., Basso, H., Smith, R. and Grasi, T. (2019), "Demographic structures and macroeconomic trends", American Economic Journal: Macroeconomics, Vol. 11 No. 1, pp. 193-222.

Almunia, M., Antras, P., López-Rodriguez, D. and Morales, E. (2020), Venting out: Exports during a Domestic Slump, Mimeo.

Autor, D. and Dorn, D. (2013), "The growth of low skill service jobs and the polarization of the US labor market", American Economic Review, Vol. 103 No. 5, pp. 1553-1597.

Autor, D., Dorn, D., Katz, L., Patterson, C. and Van Reenen, J. (2020), “The fall of the labor share and the rise of superstar firms", The Quarterly Journal of Economics, Vol. 135 No. 2, pp. 645-709.

Basso, H. and Jimeno, J.F. (2020), "From secular stagnation to Robocalypse? Implications of demographic and technological changes", Journal of Monetary Economics, forthcoming.

Bentolila, S., Dolado, J.J. and Jimeno, J.F. (2020), "Dual labour markets revisited”, Oxford Encyclopedia of Economics and Finance, Oxford University Press, Feb issue.

Blanchard, O. and Tirole, J. (2008), "Joint design of unemployment insurance and employment protection: a first pass", Journal of the European Economic Association, Vol. 6 No. 1, pp. 45-77.

Bonhomme, S. and Hospido, L. (2017), "The cycle of earnings inequality: evidence from Spanish social security data", The Economic Journal, Vol. 127 No. 603, pp. 1244-1278.

Cabrales, A., Dolado, J.J. and Mora, R. (2017), "Dual employment protection and (lack of) on-the job training: PIAAC evidence for Spain and other European countries", SERIEs Journal Series, Vol. 8 No. 4, pp. 345-371.

Calmfors, L. and Driffill, J. (1998), "Bargaining structure, corporatism and macroeconomic performance", Economic Policy, Vol. 3 No. 6, pp. 14-61.

Cerra, V.A., Fatás, A. and Saxena, S. (2020), "Hysteresis and business cycles", IMF WP 20/73.

Cocks, B. and Ghilleri, C. (2016), "Scars of recessions in a rigid labor market", Labour Economics, Vol. 41, pp. 162-176.

Dolado, J.J. (2017), "EU dual labour markets: consequences and potential reforms", in Matyas, L., Blundell, R., Cantillon, E., Chizzolini, B., Ivaldi, M., Leininger, W., Marimon, R. and Steen, F. (Eds), Economics without Borders. Economic Research for European Policy Challenges, Cambridge University Press, Cambridge.

Dolado, J.J., Lalé, E. and Siassi, N. (2020), "From dual to unified employment protection: transition and steady state", Quantitative Economics, forthcoming.

Eichenbaum, M., Rebelo, S. and Trabandt, M. (2020), The Macroeconomics of Epidemics, Mimeo.

Felgueroso, F. and de la Fuente, A. (2020), "Aspectos económicos de la crisis del Covid-19”, Boletín de Seguimiento, No. 7, Fedea.

Felgueroso, F., García-Pérez, J.I. and Jiménez, S. (2020), “Guía práctica Para evaluar los efectos sobre el empleo de la crisis del COVID-19 y el plan de Choque económico", FEDEA Economy Notes 2020-04, FEDEA.

Glover, A., Heathcote, J., Kruger, D. and Rios-Rull, J.V. (2020), Health versus Wealth: On the Distributional Effects of Controlling a Pandemic, Mimeo. 
Kaplan, G., Moll, B. and Violante, G.L. (2020), The Great Lockdown and the Big Stimulus: Tracing the Pandemic Possibility Frontier for the US, Mimeo.

Ketterman, A., Kramarz, F. and Zweimüller, J. (2017), "Job mobility and creative destruction: flexicurity in the land of Schumpeter", CEPR DP 12112.

Lazear, E.P. (1990), “Job security provisions and employment”, The Quarterly Journal of Economics, Vol. 105 No. 3, pp. 699-726.

Lazear, E., Liang, J. and Wang, H. (2014), "Demographics and entrepreneurship”, NBER WP 29506.

MCVL (2018), "Muestra continua de vidas laborales", Ministerio de Seguridad Social, Inclusión y market Migraciones, Gobierno de España.

Moral-Benito, E., García-Santana, M., Pijoan-Mas, J. and Ramos, R. (2019), "Growing like Spain: 1995-2007", International Economic Review, forthcoming, Vol. 61 No. 1.

MüLler, T. and Schulten, T. (2020), "Ensuring fair short-time work - a European overview", ETUI Policy Brief, European Economic, Employment and Social Policy N ${ }^{\circ} 7 / 2020$.

Palomino, J.C., Rodríguez, J.G. and Sebastian, R. (2020), "Wage inequality and poverty effects of lockdown and social distancing in Europe", INET Oxford Working Paper No. 2020-13.

Sebastián, R. (2018), "Explaining job polarization in Spain from a task perspective”, SERIES Journal of the Spanish Economic Association, Vol. 9, pp. 215-248.

\section{Corresponding author}

Juan J. Dolado can be contacted at: dolado@eco.uc3m.es

For instructions on how to order reprints of this article, please visit our website: 